\title{
Deoxyribonucleic Acid Relatedness of Bacillus circulans Jordan 1890 Strains
}

\author{
L. K. NAKAMURA* AND J. SWEZEY \\ Northern Regional Research Center, Agricultural Research Service, U.S. Department of Agriculture, Peoria, \\ Illinois 61604
}

\begin{abstract}
Deoxyribonucleic acid reassociation measurements revealed that 50 of 111 Bacillus circulans Jordan 1890 strains examined could be separated into 10 groups of genetically related organisms. The results of deoxyribonucleic acid relatedness studies and phenotypic comparisons suggested that five of these groups were hitherto undescribed species and that four others probably represented previous ly, but inadequately, described species. The tenth group, which included the type strain, represented the species $B$. circulans sensu stricto. Our data show that $B$. circulans and Bacillus macerans Schardinger 1905 are genetically and phenotypically distinct species. Thus, the phenotypic heterogeneity of the species $B$. circulans sensu lato is not due to inherent variability of genetically related strains but rather is due to inclusion of genetically unrelated organisms in this taxon.
\end{abstract}

Jordan described the species Bacillus circulans in 1890 (8). In 1916, Ford isolated a morphologically dissimilar strain but classified it as $B$. circulans because, like the strain of Jordan, its colonies also displayed internal circular movement (4). The strain of Jordan has been lost. Because strain 26 of Ford is the only historical strain available, it has been designated as the type strain.

Continued studies by other researchers have disclosed a morphologically, nutritionally, physiologically, immunologically, and chemically heterogeneous group $(1,6,7,10,12,13)$. Our studies have established that of 123 strains identified as $B$. circulans, only 17 have guanine-pluscytosine $(\mathrm{G}+\mathrm{C})$ contents $(37$ to $40 \mathrm{~mol} \%)$ like the type strain. Deoxyribonucleic acid (DNA) reassociation experiments have revealed that 10 of these 17 strains are closely related to each other and to the type strain (9). The present study was undertaken to determine by DNA reassociation experiments the taxonomic position of the strains misclassified as B. circulans. Our data suggest that at least five hitherto undescribed species and four previously, but inadequately, described species may be misclassified as $B$. circulans.

\section{MATERIALS AND METHODS}

Bacterial strains. The $B$. circulans strains used in this study have been listed previously (9). Also included in this study were strains NRRL NRS-18, NRRL NRS-609, NRRL NRS-888, and NRRL NRS-1105, the type strains of Bacillus stearothermophilus Donk 1920, Bacillus coagulans Hammer 1915, Bacillus macerans Schardinger 1905, and Bacillus polymyxa (Prazmowski) Mace 1889, respectively.

Characterization. The strains were characterized as described by Nakamura and Swezey (9). In this study we also tested for urease activity by the method of Edwards and Ewing (3).

DNA isolation, $\mathrm{G}+\mathrm{C}$ ratios, and DNA reassociation. The procedures used for DNA isolation and final purification by hydroxyapatite chromatography and for estimation of DNA reassociation values by spectrophotometric measurement of renaturation rates have been described previously (9). The equation of De Ley et al. (2) was used to calculate the reassociation values (percentages). All determinations of DNA reassociation values were repeated twice.

To determine the $\mathrm{G}+\mathrm{C}$ content, the buoyant density of a DNA was measured by $\mathrm{CsCl}$ density gradient centrifugation; the internal standard which we used was Micrococcus luteus (synonym, "Micrococcus lysodeikticus"') DNA purchased from Sigma Chemical Co., St. Louis, Mo. (11).

\section{RESULTS}

Because a large number of strains were involved, DNA reassociation values were determined only among organisms segregated according to similarities in $\mathrm{G}+\mathrm{C}$ contents or phenotypic characteristics or both. Such determinations established that 50 of the 111 strains identified as $B$. circulans could be separated into 10 distinct DNA relatedness groups (Table 1), each consisting of a reference strain and organisms genetically related to it. Experiments showed that the extent of DNA reassociation among members of any one group was high (70 to $100 \%$ ). However, intergroup DNA reassociation values were consistently low (35\% or less). The largest group (group 1) consisted of nine organisms and the type strain of $B$. circulans (strain NRRL NRS-726), and these organisms had $\mathrm{G}+\mathrm{C}$ contents of 37.4 to $38.9 \mathrm{~mol} \%$. The remaining nine groups (groups 2 through 10) 
TABLE 1. DNA relatedness of selected $B$. circulans strains

\begin{tabular}{|c|c|c|c|c|c|c|c|c|c|c|c|c|}
\hline \multirow{2}{*}{$\begin{array}{l}\text { Group } \\
\text { or } \\
\text { species }\end{array}$} & \multirow[b]{2}{*}{$\begin{array}{c}\text { Strain } \\
\text { (NRRL no.) }\end{array}$} & \multirow{2}{*}{$\begin{array}{c}\mathrm{G}+\mathrm{C} \\
\text { content } \\
(\mathrm{mol} \%)\end{array}$} & \multicolumn{10}{|c|}{$\%$ Reassociation with DNA from strain: ${ }^{a}$} \\
\hline & & & $\begin{array}{l}\text { NRRL } \\
\text { NRS- } \\
726^{\text {Tb }}\end{array}$ & $\begin{array}{c}\text { NRRL } \\
\text { NRS- } \\
1434\end{array}$ & $\begin{array}{c}\text { NRRL } \\
\text { NRS- } \\
1347\end{array}$ & $\begin{array}{c}\text { NRRL } \\
\text { NRS- } \\
1346\end{array}$ & $\begin{array}{c}\text { NRRL } \\
\text { BD- } \\
537\end{array}$ & $\begin{array}{l}\text { NRRL } \\
\text { NRS- } \\
1173\end{array}$ & $\begin{array}{c}\text { NRRL } \\
\text { NRS- } \\
381\end{array}$ & $\begin{array}{c}\text { NRRL } \\
\text { NRS- } \\
666\end{array}$ & $\begin{array}{l}\text { NRRL } \\
\text { NRS- } \\
838 \mathrm{a}\end{array}$ & $\begin{array}{l}\text { NRRL } \\
\text { NRS- } \\
290\end{array}$ \\
\hline $1^{c}$ & & $37.4-38.9^{d}$ & $63-100^{d}$ & & & & & & & & & \\
\hline \multirow[t]{3}{*}{2} & NRS-1434 & 45.6 & 15 & $(100)^{e}$ & & & & & & & & \\
\hline & NRS-1435 & 45.6 & 28 & 81 & & & & & & & & \\
\hline & NRS-1436 & 46.2 & 21 & 94 & & & & & & & & \\
\hline \multirow[t]{3}{*}{3} & NRS-1347 & 47.5 & 18 & 26 & $(100)$ & & & & & & & \\
\hline & NRS-1348 & 49.1 & $\mathrm{ND}^{f}$ & 20 & 76 & & & & & & & \\
\hline & NRS-1350 & 47.3 & 20 & 22 & 85 & & & & & & & \\
\hline \multirow[t]{3}{*}{4} & NRS-1346 & 47.1 & 10 & 2 & 35 & $(100)$ & & & & & & \\
\hline & NRS-1349 & 48.5 & 9 & 7 & 18 & 98 & & & & & & \\
\hline & NRS-1351 & 47.0 & ND & 2 & 26 & 100 & & & & & & \\
\hline \multirow[t]{6}{*}{5} & B-745 & 48.5 & ND & 34 & 10 & 24 & 98 & & & & & \\
\hline & B-1373 & 47.8 & ND & 20 & 6 & 21 & 93 & & & & & \\
\hline & B-1488 & 48.1 & 16 & 22 & 9 & 19 & 89 & & & & & \\
\hline & BD-536 & 50.0 & ND & 18 & 14 & 25 & 100 & & & & & \\
\hline & BD-537 & 48.7 & ND & 9 & 10 & 29 & $(100)$ & & & & & \\
\hline & NRS-924 & 49.9 & 14 & 20 & 9 & 20 & 78 & & & & & \\
\hline \multirow[t]{6}{*}{6} & NRS-1173 & 48.4 & ND & 34 & 22 & 28 & 6 & $(100)$ & & & & \\
\hline & NRS-1174 & 49.5 & 12 & ND & 19 & 20 & 9 & 86 & & & & \\
\hline & NRS-1175 & 47.6 & ND & 16 & 26 & 22 & 12 & 100 & & & & \\
\hline & NRS-1177 & 49.5 & 12 & 23 & 24 & 17 & 10 & 84 & & & & \\
\hline & NRS-1343 & 50.2 & ND & ND & 17 & 25 & 5 & 71 & & & & \\
\hline & NRS-1356 & 47.8 & ND & 11 & 26 & 18 & 10 & 77 & & & & \\
\hline \multirow[t]{5}{*}{7} & NRS-381 & 51.4 & 2 & 25 & 27 & 24 & 10 & 15 & $(100)$ & & & \\
\hline & NRS-382 & 51.7 & ND & 11 & ND & ND & 4 & 20 & 94 & & & \\
\hline & NRS-383 & 50.9 & ND & ND & 32 & ND & ND & 18 & 92 & & & \\
\hline & NRS-384 & 51.8 & ND & 15 & ND & 7 & 6 & ND & 100 & & & \\
\hline & NRS-386 & 50.3 & 8 & ND & 25 & 20 & ND & ND & 100 & & & \\
\hline \multirow[t]{5}{*}{8} & NRS-666 & 51.5 & 2 & 3 & 26 & 10 & 8 & 10 & 25 & (100) & & \\
\hline & NRS-676 & 51.2 & ND & 12 & 20 & 3 & 9 & 14 & 27 & 75 & & \\
\hline & NRS-678 & 50.2 & 2 & ND & ND & 17 & ND & ND & 26 & 70 & & \\
\hline & NRS-679 & 50.9 & ND & 10 & 13 & 3 & 12 & 20 & 20 & 84 & & \\
\hline & NRS-1171 & 51.5 & ND & ' ND & ND & ND & ND & ND & 30 & 100 & & \\
\hline \multirow[t]{5}{*}{9} & NRS- 625 & 53.6 & 9 & 2 & 10 & 8 & 14 & 14 & 10 & 16 & 79 & \\
\hline & NRS-639 & 54.1 & ND & ND & ND & 11 & ND & 12 & 12 & 10 & 100 & \\
\hline & NRS-838a & 54.4 & 8 & 16 & 12 & ND & 8 & ND & 18 & 20 & $(100)$ & \\
\hline & NRS-839a & 53.3 & ND & ND & 15 & ND & ND & 19 & 15 & 23 & 98 & \\
\hline & NRS-1000 & 53.9 & 3 & 12 & ND & 18 & 13 & ND & 17 & 14 & 100 & \\
\hline
\end{tabular}




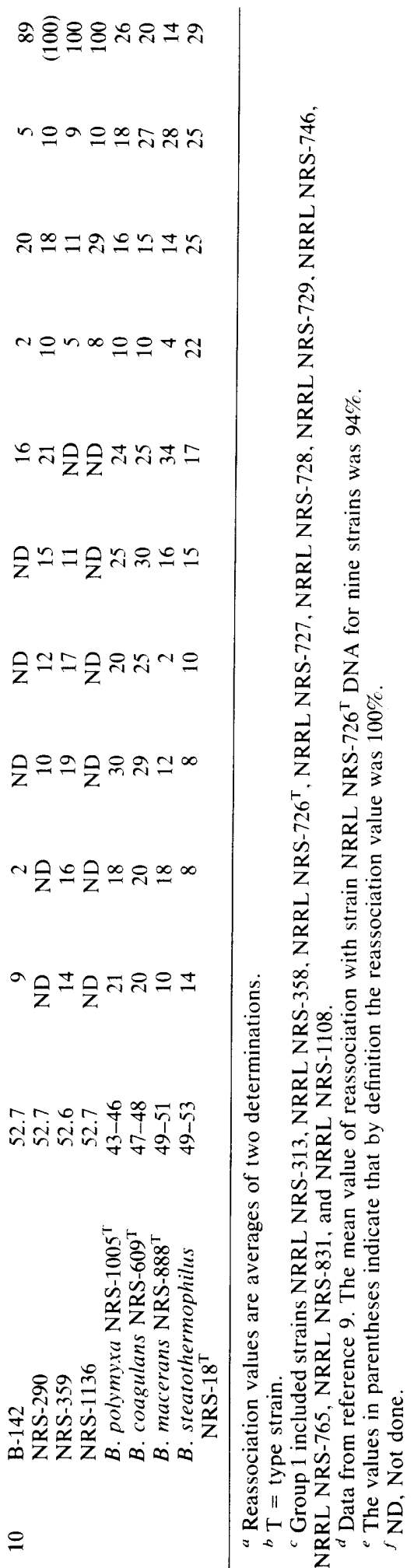

contained from three to six members. The strains in groups 2 through 6 had $\mathrm{G}+\mathrm{C}$ contents that ranged from 45.6 to $50.2 \mathrm{~mol} \%$. In groups 7 through 10 , the $\mathrm{G}+\mathrm{C}$ contents ranged from 50.3 to $54.4 \mathrm{~mol} \%$. DNAs with $\mathrm{G}+\mathrm{C}$ contents that range from 45 to $54 \mathrm{~mol} \%$ have been found in $B$. coagulans, $B$. macerans, $B$. polymyxa, and $B$. stearothermophilus (5). Our low DNA relatedness values suggested that none of the nine groups was related genetically to these four established species (Table 1).

Table 2 shows a comparison of the phenotypic characteristics of the 10 DNA relatedness groups. In general, whereas the groups showed pronounced phenotypic heterogeneity, individuals within groups were highly homogeneous. All of the groups were catalase positive and were negative for acetylmethylcarbinol production (Voges-Proskauer [VP] test), oxidase, egg yolk lecithinase, $\mathrm{H}_{2} \mathrm{~S}$ production, and growth at $55^{\circ} \mathrm{C}$ or higher. Except for group 7, all of the groups were active carbohydrate fermenters.

Group 11 consisted of 61 strains that gave low DNA reassociation values ( $30 \%$ or less) with the reference strains of the first 10 groups. The $\mathrm{G}+\mathrm{C}$ contents of these strains ranged from 43 to 55 mol\%. The characteristics of group 11 are summarized in Table 2 . This group was highly heterogeneous, a condition that appropriately describes the species $B$. circulans in its present state.

\section{DISCUSSION}

On the basis of DNA reassociation studies, 10 distinct groups were identified among 111 strains identified as $B$. circulans. As reported previously (9), because the major group (group 1) contains the type strain, this group represents the species $B$. circulans sensu stricto. According to Table 2, this $B$. circulans group is phenotypically distinct from the other nine DNA relatedness groups. Furthermore, in contrast to the statement in Bergey's Manual of Determinative Bacteriology, 8th ed. (5), $B$. circulans is distinguishable from $B$. macerans by differences in the following characteristics: growth in $5 \% \mathrm{NaCl}$, utilization of citrate, reduction of nitrate to nitrite, and $\mathrm{G}+\mathrm{C}$ content (Table 3 ). The level of DNA relatedness between the two species is low (Table 1).

Ranging from 45 to $54 \mathrm{~mol} \%$, the $\mathrm{G}+\mathrm{C}$ contents of groups 2 through 10 encompass the range of base contents of DNAs from a group of known species which includes $B$. coagulans Hammer 1915, B. macerans Schardinger 1905 , $B$. polymyxa (Prazmowski) Macer 1889, and $B$. stearothermophilus Donk 1920. However, low DNA relatedness values indicate that none of these nine groups is related to these four established species. 
TABLE 2. Characteristics of the DNA relatedness groups

\begin{tabular}{|c|c|c|c|c|c|c|c|c|c|c|c|}
\hline \multirow[b]{2}{*}{ Characteristic } & \multicolumn{11}{|c|}{ Group $^{a}$} \\
\hline & $\begin{array}{c}1 \\
(n=10)^{b}\end{array}$ & $\begin{array}{c}2 \\
(n=3)\end{array}$ & $\begin{array}{c}3 \\
(n=3)\end{array}$ & $(n \stackrel{4}{=} 3)$ & $\begin{array}{c}5 \\
(n=6)\end{array}$ & $\begin{array}{c}6 \\
(n=6)\end{array}$ & $\stackrel{7}{(n=5)}$ & $\begin{array}{c}8 \\
(n=5)\end{array}$ & $\begin{array}{c}9 \\
(n=5)\end{array}$ & $\begin{array}{c}10 \\
(n=4)\end{array}$ & $\begin{array}{c}11 \\
(n=61)\end{array}$ \\
\hline $\begin{array}{l}\text { Growth under } \\
\text { anaerobic } \\
\text { conditions }\end{array}$ & $10^{c}$ & 3 & 0 & 0 & 6 & 6 & 0 & 5 & 5 & 5 & $\mathrm{ND}^{d}$ \\
\hline Growth in $3 \% \mathrm{NaCl}$ & 10 & 0 & 0 & 1 & 5 & 4 & 0 & 5 & 0 & 4 & 29 \\
\hline Growth in $5 \% \mathrm{NaCl}$ & 10 & 0 & 0 & 0 & 2 & 0 & 0 & 5 & 0 & 1 & 12 \\
\hline Growth in $7 \% \mathrm{NaCl}$ & 7 & 0 & 0 & 0 & 0 & 0 & 0 & 0 & 0 & 0 & 3 \\
\hline Growth at pH 5.6 & 10 & 3 & 3 & 3 & 6 & 4 & 4 & 0 & 5 & 4 & 40 \\
\hline $\begin{array}{l}\text { Growth with } \\
\text { lysozyme }\end{array}$ & 0 & 0 & 3 & 0 & 0 & 0 & 5 & 5 & 0 & 4 & 15 \\
\hline Growth at $55^{\circ} \mathrm{C}$ & 0 & 0 & 0 & 0 & 0 & 0 & 0 & 0 & 0 & 0 & ND \\
\hline Hydrolysis of: & & & & & & & & & & & \\
\hline Casein & 0 & 3 & 0 & 1 & 5 & 0 & 0 & 0 & 0 & 0 & 17 \\
\hline Starch & 10 & 0 & 3 & 3 & 6 & 6 & 0 & 5 & 5 & 4 & 39 \\
\hline Tween 80 & 9 & 3 & 3 & 3 & 0 & 2 & 1 & 0 & 5 & 0 & 26 \\
\hline $\begin{array}{l}\text { Nitrate reduced to } \\
\text { nitrite }\end{array}$ & 0 & 0 & 0 & 0 & 0 & 0 & 0 & 5 & 0 & 4 & 28 \\
\hline VP test & 0 & 0 & 0 & 0 & 0 & 0 & 0 & 0 & 0 & 0 & 6 \\
\hline Urease activity & 0 & 3 & 2 & 3 & 0 & 6 & 0 & 5 & 5 & 1 & 36 \\
\hline Egg yolk lecithinase & 0 & 0 & 0 & 0 & 0 & 0 & 0 & 0 & 0 & 0 & 3 \\
\hline $\mathrm{H}_{2} \mathrm{~S}$ production & 0 & 0 & 0 & 0 & 0 & 0 & 0 & 0 & 0 & 0 & 2 \\
\hline Catalase & 10 & 3 & 3 & 3 & 6 & 6 & 5 & 5 & 5 & 4 & 61 \\
\hline Oxidase & 0 & 0 & 0 & 0 & 0 & 0 & 0 & 0 & 0 & 0 & 2 \\
\hline $\begin{array}{l}\mathrm{pH} \text { in VP broth } \\
<5.5\end{array}$ & 10 & 0 & 0 & 0 & 5 & 6 & 0 & 5 & 0 & 4 & 40 \\
\hline Indole & 0 & 0 & 0 & 0 & 0 & 0 & 0 & 0 & 0 & 0 & 1 \\
\hline Utilization of: & & & & & & & & & & & \\
\hline Acetate & 10 & 3 & 3 & 2 & 6 & 6 & 5 & 5 & 5 & 2 & 49 \\
\hline Citrate & 0 & 0 & 0 & 0 & 0 & 0 & 0 & 0 & 5 & 0 & 20 \\
\hline Fumarate & 10 & 3 & 3 & 0 & 0 & 0 & 5 & 0 & 5 & 0 & 24 \\
\hline Malate & 10 & 3 & 3 & 2 & 0 & 0 & 5 & 0 & 5 & 0 & 25 \\
\hline Succinate & 1 & 3 & 3 & 0 & 0 & 0 & 5 & 0 & 5 & 0 & 21 \\
\hline Fermentation of: & & & & & & & & & & & \\
\hline Arabinose & 10 & 3 & 3 & 3 & 6 & 6 & 0 & 5 & 5 & 4 & 53 \\
\hline Cellobiose & 10 & 3 & 3 & 3 & 6 & 6 & 0 & 5 & 5 & 4 & 59 \\
\hline Fructose & 10 & 3 & 3 & 3 & 6 & 6 & 0 & 5 & 5 & 4 & 61 \\
\hline Galactose & 10 & 3 & 3 & 3 & 6 & 6 & 5 & 5 & 5 & 4 & 59 \\
\hline Glucose & 10 & 3 & 3 & 3 & 6 & 6 & 5 & 5 & 5 & 4 & 61 \\
\hline Lactose & 10 & 3 & 3 & 3 & 6 & 6 & 5 & 5 & 5 & 4 & 55 \\
\hline Maltose & 10 & 3 & 3 & 3 & 6 & 6 & 5 & 5 & 5 & 4 & 61 \\
\hline Mannitol & 10 & 3 & 3 & 3 & 6 & 6 & 5 & 5 & 5 & 4 & 53 \\
\hline Mannose & 10 & 3 & 3 & 3 & 6 & 6 & 0 & 5 & 5 & 4 & 61 \\
\hline Melibiose & 10 & 3 & 3 & 3 & 6 & 6 & 0 & 5 & 5 & 4 & 56 \\
\hline Rhamnose & 10 & 3 & 3 & 3 & 6 & 6 & 5 & 5 & 5 & 1 & 41 \\
\hline Ribose & 10 & 3 & 3 & 3 & 6 & 6 & 5 & 5 & 5 & 4 & 59 \\
\hline Salicin & 10 & 3 & 3 & 3 & 6 & 6 & 5 & 5 & 5 & 4 & 59 \\
\hline Sorbitol & 10 & 3 & 0 & 0 & 1 & 2 & 0 & 0 & 5 & 0 & 21 \\
\hline Sucrose & 10 & 3 & 3 & 3 & 6 & 6 & 5 & 5 & 5 & 4 & 61 \\
\hline Trehalose & 10 & 3 & 3 & 3 & 6 & 6 & 5 & 5 & 5 & 4 & 61 \\
\hline Xylose & 10 & 3 & 3 & 3 & 6 & 6 & 5 & 5 & 5 & 4 & 58 \\
\hline
\end{tabular}

${ }^{a}$ Groups 1 through 10 were composed of organisms showing DNA relatedness. Group 11 contained all strains not included in the 10 groups of related strains.

${ }^{b}$ Number of strains in the group.

c Number of positive strains.

${ }^{d}$ ND, Not done.

Phenotypically, the inability of the members of the groups to grow at $55^{\circ} \mathrm{C}$ eliminates classification as either $B$. coagulans or $B$. stearothermophilus (Table 3). Furthermore, in contrast to groups 2 through $10, B$. coagulans gives a positive VP test, and B. stearothermophilus does not ferment arabinose, mannitol, or xylose.

Because groups 2 through 10 are VP test 
TABLE 3. Characteristics for differentiating groups 1 through 10 from B. coagulans, B. macerans, B. polymyxa, and B. stearothermophilus

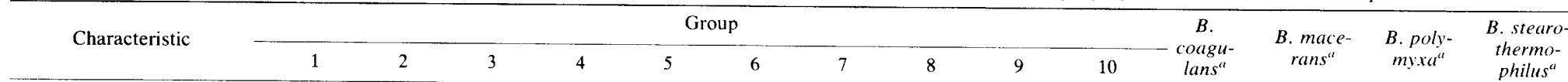

Growth in

$5 \% \mathrm{NaCl}$

$7 \% \mathrm{NaCl}$

Growth at $\mathrm{pH} 5.6$

Growth with lysozyme

Growth under anaerobic

conditions

Growth at $55^{\circ} \mathrm{C}$

Hydrolysis of:

Starch

Casein

VP test

Nitrate reduced to nitrite

Citrate utilization

Fermentation of:

Glucose

Arabinose

Xylose

Mannitol

$\begin{array}{cccccc}+^{b} & - & - & - & \mathrm{v} & - \\ - & - & - & - & - & - \\ + & + & + & + & + & \mathrm{v} \\ - & - & + & - & - & - \\ + & + & - & - & + & + \\ - & - & - & - & - & - \\ & & & & & \\ + & - & + & + & + & + \\ - & + & - & v & v & - \\ - & - & - & - & - & - \\ - & - & - & - & - & - \\ - & \mathrm{v} & - & - & - & - \\ & & & & & \\ + & + & + & + & + & + \\ + & + & + & + & + & + \\ + & + & + & + & + & + \\ + & + & + & + & + & + \\ 7-39 & 45-46 & 47-49 & 47-48 & 47-50 & 47-50\end{array}$

\begin{tabular}{|c|c|}
\hline- & - \\
\hline- & - \\
\hline $\mathrm{v}$ & $\mathrm{v}$ \\
\hline- & + \\
\hline+ & - \\
\hline - & - \\
\hline+ & - \\
\hline- & - \\
\hline- & - \\
\hline- & - \\
\hline- & - \\
\hline+ & + \\
\hline+ & - \\
\hline+ & + \\
\hline+ & + \\
\hline
\end{tabular}

$\mathrm{G}+\mathrm{C}$ content $(\mathrm{mol} \%)$ $37-39 \quad 45-46$

$47-50$

$47-50$

$50-52 \quad 50-52$

$\begin{array}{cccc}+ & - & \mathrm{v} & - \\ - & - & - & - \\ - & + & + & + \\ + & - & + & - \\ + & + & + & + \\ & & & \\ - & - & - & + \\ + & + & + & + \\ - & - & - & + \\ - & - & - & + \\ + & - & + & \mathrm{v} \\ - & + & - & \mathrm{v} \\ & & & \\ + & + & + & + \\ + & + & + & \mathrm{v} \\ + & + & + & \mathrm{v} \\ + & + & + & \mathrm{v} \\ -52 & 53-54 & 50-53 & 47-48\end{array}$

$\begin{array}{ll}- & - \\ - & - \\ + & + \\ \mathrm{v} & - \\ + & + \\ & \\ - & - \\ + & + \\ - & + \\ - & + \\ + & + \\ + & - \\ \oplus & \oplus \\ \oplus & \oplus \\ \oplus & \oplus \\ \oplus 5 & \oplus\end{array}$

" Data from reference 5 .

$b+$, Positive; - , negative; $v$, variable; $\oplus$, positive with gas production. 
negative and largely negative for citrate utilization, reduction of nitrate to nitrite, and caseinase activity, they are probably not related to $B$. polymyxa, which is VP test positive, reduces nitrate to nitrite, and hydrolyzes casein (Table 3). Groups 8 and 10 reduce nitrate to nitrite but do not hydrolyze casein. Groups 2 and 5 hydrolyze casein but do not reduce nitrate.

$B$. macerans is VP test negative, reduces nitrate to nitrite, and utilizes citrate. Since they are negative for all three of these tests, groups 2 through 7 are most likely not related to $B$. macerans (Table 3). Although groups 8 and 10 reduce nitrate to nitrite, their ability to grow in lysozyme and their failure to utilize citrate differentiate them from $B$. macerans. Group 9 differs from $B$. macerans in not being able to reduce nitrate to nitrite.

DNA relatedness measurements and phenotypic studies have revealed that the majority of the strains which we examined have been erroneously classified as $B$. circulans. According to our results, among the 111 erroneously classified organisms there were nine genetically unrelated groups (hence, nine distinct species). Members of five of these nine groups may represent species that have not been described previously, and some of the strains in four of the groups were originally classified as species other than $B$. circulans. For example, group 5 includes strain NRRL NRS-924, which was received as “Bacillus pabuli"' Schieblich 1923. Group 8 contains strain NRRL NRS-666, which was received as "Bacillus lautus" Batchelor 1919. Included in group 9 are strains NRRL NRS-625 and NRRL NRS-626, which were received as "Bacillus nitidus" Bredemann and Heigener 1935; strains NRRL NRS-639 and NRRL NRS1000 , which were received as "Bacillus validus" Bredemann and Heigener 1935; and strains NRRL NRS-838a and NRRL NRS-839a, which were contaminants of a culture identified as "Bacillus cohaerens" Meyer and Gottheil 1901. Strain NRRL NRS-290 in group 10 was received as "Bacillus amylolyticus" Kellerman and MacBeth 1912. The above observations suggest that group 5 could be classified as " $B$. pabuli", group 8 could be classified as " $B$. lautus", group 9 could be classified as " $B$. nitidus" or " $B$. validus", and group 10 could be classified as " $B$. amylolyticus".

Also present were 61 strains which were not genetically related to groups 1 through 10 and displayed widely varying characteristics. Consequently, the phenotypic heterogeneity of $B$. circulans is not due to the inherent variability of genetically related strains but is derived from the inclusion of a number of unrelated organisms in this taxon.

\section{ACKNOWLEDGMENTS}

We thank Tracy Tarbuck and Brent Rafferty for able technical assistance.

\section{LITERATURE CITED}

1. Bradley, D. E., and J. G. Franklin. 1958. Electron microscopy survey of the surface configuration of spores of the genus Bacillus. J. Bacteriol. 76:618-630.

2. De Ley, J., H. Cattoir, and A. Reynaerts. 1970. The quantitative measurement of DNA hybridization from renaturation rates. Eur. J. Biochem. 12:133-142.

3. Edwards, P. R., and W. H. Ewing. 1972. Identification of Enterobacteriaceae. Burgess Publishing Co., Minneapolis.

4. Ford, W. W. 1916. Studies on aerobic spore-bearing nonpathogenic bacteria. II. Miscellaneous cultures. J. Bacteriol. 1:518-526.

5. Gibson, T., and R. E. Gordon. 1974. Genus 1. Bacillus Cohn 1872, p. 529-550. In R. E. Buchanan and N. E. Gibbons (ed.), Bergey's manual of determinative bacteriology, 8th ed. The Williams \& Wilkins Co., Baltimore.

6. Hill, I. R., and T. R. G. Gray. 1967. Application of the fluorescent-antibody technique to an ecological study of bacteria in soil. J. Bacteriol. 93:1888-1896.

7. Jayne-Williams, D. J., and G. C. Cheeseman. 1960. The differentiation of bacterial species by paper chromatography. IX. The genus Bacillus: a preliminary investigation. J. Appl. Bacteriol. 23:250-268.

8. Jordan, E. O. 1890 . A report on certain species of bacteria observed in sewage, p. 821-844. In W. T. Sedgewick (ed.), A report of the biological work of the Lawrence Experiment Station, including an account of methods employed and results obtained in the microscopical and bacteriological investigation of sewage and water. Report on water supply and sewerage, part 2. Massachusetts State Board of Health, Boston.

9. Nakamura, L. K., and J. Swezey. 1983. Taxonomy of Bacillus circulans Jordan 1890: base composition and reassociation of deoxyribonucleic acid. Int. J. Syst. Bacteriol. 33:46-52.

10. Proom, H., and B. C. J. G. Knight. 1955. The minimal nutritional requirements of some species of the genus Bacillus. J. Gen. Microbiol. 13:474-480.

11. Schildkraut, C. L., J. Marmur, and P. Doty. 1962. Determination of the base composition of deoxyribonucleic acid from its buoyant density in $\mathrm{CsCl}$. J. Mol. Biol. 4:430 443.

12. Smith, N. R., R. E. Gordon, and F. E. Clark. 1952. Aerobic sporeforming bacteria. Agriculture monograph 16 U.S. Department of Agriculture, Washington, D.C.

13. Wolf, J., and M. S. U. Chowdhury. 1971. The Bacillus circulans complex: biochemical and immunological studies, p. 227-245. In A. N. Barker, G. W. Gould, and J. Wolf (ed.), Spore research 1971. Academic Press, Inc., New York. 